\title{
FOREST RELATED LEGISLATION IN SOME WESTERN BALKAN COUNTRIES REFERRING TO NATURE PROTECTION REGULATIONS
}

\author{
Odredbe o zaštiti prirode u šumarskoj legislativi nekih zemalja Zapadnog \\ Balkana
}

\begin{abstract}
Amila Brajićc ${ }^{1}$, Senka Mutabdžija ${ }^{1}$, Mersudin Avdibegović ${ }^{1}$, Bruno Marić ${ }^{1}$, Dženan Bećirović ${ }^{1}$, Todora Grašić ${ }^{2}$, Vladimir Nikolić ${ }^{2}$, Radovan Nevenićc ${ }^{3}$, Špela Pezdevšek Malovrh ${ }^{4}$
\end{abstract}

\begin{abstract}
Within last few years, all Western Balkan countries have adopted new forest legislation aiming to introduce internationally accepted concepts of forest management. Due to specific social, political and economical realities that these countries have passed through, a number of nature protection regulations have been integrated into forest legislation. This paper compares nature protection regulations in Laws on Forests in Croatia (2005), Federation of Bosnia and Herzegovina (2002) and Serbia (2010). It examines differences and commonalities in above mentioned Laws. Furthermore, the paper analyzes the level of consistencies between Laws on Forests and Laws on Nature Protection in Croatia (2005), Federation of Bosnia and Herzegovina (2003) and Serbia (2009) in terms of "openness" and "greening" of forest related legislation. The results show that protection regulations within forest legislation, particularly those referring to forests with special management regime, can be strengthened by introducing the concept of high conservation value forests (HCVF). This concept includes also strategic changing of forestry sector position from an inferior towards more proactive role in nature protection dialogue. The results of this paper can contribute to further improvements of current countries' forest related legislation in domain of analyzed issues as well as creation of consistent forest and nature protection policies aimed at fostering cross-sectoral dialogue and cooperation.
\end{abstract}

Key words: forest related legislation, nature protection regulations, Western Balkan countries, high conservation value forests.

\footnotetext{
${ }^{1}$ Faculty of Forestry, University of Sarajevo, Zagrebačka 20, 71000 Sarajevo, Bosnia-Herzegovina

${ }^{2}$ Faculty of Forestry, University of Belgrade, Kneza Višeslava 1, 11000 Belgrade, Serbia

${ }^{3}$ Institute for Forestry, Kneza Višeslava 3, 11000 Belgrade, Serbia

${ }^{4}$ Biotechnical Faculty, University of Ljubljana, Večni pot 83, 1000 Ljubljana, Slovenia
} 


\section{INTRODUCTION - Uvod}

The period of transition in Western Balkan countries has brought considerable changes in their respective societies. By increasing of public awareness about the importance of forests for overall wellbeing, foresters have been faced with the new challenge - once traditional sector and its legislation, based mainly on technocratic knowledge, needs to become more open and "greener". Although some drivers of changes lay down in transition process itself, the EU accession, which includes international nature protection principles, is still the prevailing factor towards adaptation and implementation of the new forest legislation in the Western Balkan countries. Doubtless, forestry professionals cannot anymore create policy actions by applying the traditional, control-based instruments of forest policy, among which Laws on Forests are known as the most frequently-used ones. Therefore, it is needed to understand weather, how and to which extent nature protection regulations are incorporated in Laws on Forests.

Despite of the importance of this topic, few papers dealing with "greening" of forest legislation in Western Balkan countries have been published so far. These were focusing basically on changes, collisions and harmonization of Laws on Forests and Laws on Nature Protection at the national level (MARTINIĆ, 2000; AVDIBEgOVIĆ, 2002; PROKIĆ, 2003; StANIŠIĆ ET AL, 2005; TOMIĆ, 2006; AVDIBEGOVIĆ ET AL, 2006; MARTINIĆ ET AL, 2009). One can identify a lack of thorough cross-sectoral analysis as well as missing of cross-countries comparisons as a common weakness of these papers. Such comparisons are very much needed in transition period due to fast changes and constant improvement of national legislation. Furthermore, each of Western Balkan countries has different progress towards harmonization of their legislation with the EU standards, so an appropriate benchmarking among the countries is both, promising research topic and useful exercise for further improvements of national legislations.

The audience of this paper is primarily public forest administration (decision makers) as they have a mandate to follow the international trends in forest legislation development and improve it accordingly. On the other hand, this paper might be of interest for professionals from both, forestry and nature protection sectors, as they face day-to-day challenges in implementation process. Nature protection professionals might be interested in how the regulations of nature protection are implemented in forest management, while foresters should benefit from cross-country comparative analysis of forest legislation in terms of its consistency with nature protection legislation.

This paper is driven by the idea that protection regulations have to be appropriately incorporated in the Laws on Forests. However, enforcement of the legislation heavily depends on harmonization between forest and nature protection legislation. Different social, political and economical realities in particular states, influence differences on how forest related legislation refers to nature protection issues. The "greener" forest legislation, the better its effectiveness from the perspective of current demands of the society towards forest resources. 


\section{MATERIAL AND RESEARCH METHODS - Materijal i metode istraživanja}

The objective of this paper is to explore whether and how nature protection regulations are incorporated into national Laws on Forests in the Republic of Croatia (hereinafter Croatia), the Federation of Bosnia-Herzegovina (hereinafter F B-H) and the Republic of Serbia (hereinafter Serbia). In order to fulfill this objective, an appropriate conceptual framework based on the idea that any Law on Forests is consisting of three main pillars (protection, land-use and utilization regulations) (SCHMITHÜSEN, 2004) has been designed (Figure 1). This paper deals only with the segment referring to protection regulations (environment and biodiversity, nature and landscape, soil and water resources, cultural and spiritual values) focusing on changes in forest-related legislation and its interactions with nature protection legislation. Unprecedented scale of socio-political changes which happened in relatively short time significantly changed society demands towards forests in all three countries. Among the other needs of society, nature protection is clearly recognized and widely accepted by general public.

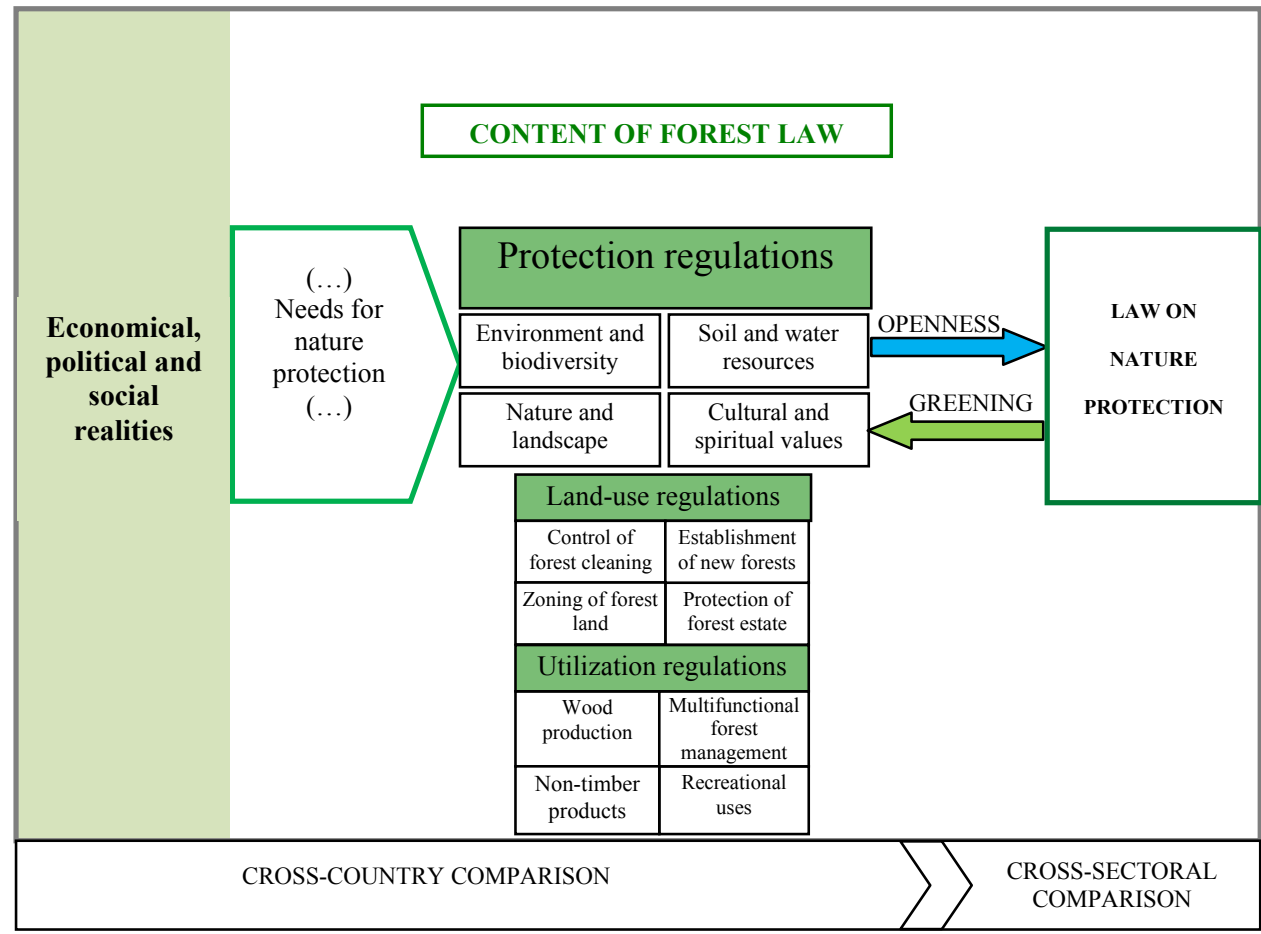

Figure 1: Conceptual framework for forest legislative analysis referring to nature protection Slika 1: Konceptualni okvir za analizu odredbi o zaštiti prirode u šumarskoj legislativi 
Some specific aspects were analyzed and cross-country compared in the Laws on Forests of all 3 countries (Croatia, F B-H and Serbia). The scale of "green" regulations related to nature protection, presented in Laws on Forests, directly influence the level of "openness" of the Laws on Forests against the concept of nature protection (e.g. its referring to cross-sectoral cooperation related to nature protection issues). To be able to understand some specific elements of protection regulations (e.g. nature and landscape, cultural and spiritual values etc.), it was useful to analyze provisions related to protective and special-purpose forests, defined by the Laws on Forests. Furthermore, this paper investigates the level of harmonization of national Laws on Forests and Laws on Nature Protection in above mentioned aspects. By doing so, the issue of nature protection prescribed by forest related legislation is analyzed from two dimensions, cross-country and cross-sectoral.

\section{RESULTS AND DISCUSSION - Rezultati i diskusija}

The introductory article of Law on Forests in Croatia (Official GaZETTE CROATIA NO. 140/05) prescribes that forests (as natural resource) are managed with the objective to preserve biological diversity, based on the principles of economic sustainability, social responsibility and ecological acceptability. The Law on Forests of F B-H points out that the main objective (among others) is to regulate preservation and protection of forests as well as strengthening of ecological functions of forests. It also defines financing of regeneration and enhancement of forests. The same also holds for the Serbian Law on Forests where the main purpose is prescribed in regulations of forest conservation, protection, planning, silviculture, utilization and management of forests and forest lands. By defining the issues related to protection, land use and utilization, one can conclude that each of above mentioned Laws on Forests comprise the above mentioned three pillars of any Law on Forests. Furthermore, each of the Laws is treating forests as resources of particular interests for the society. Forests are defined either as resources of national interest (Article 2 of the Law on Forests in Croatia), or good of general interests (Article 1 of the Law on Forests of F B-H) or good of public interests (Article 3 of Law on Forests of Serbia). Despite of different terminology, each of the Laws considers forests as resource of tremendous importance that should enjoy special protection and esteem of general public due to its multiple functions (i.e. in Article 4 of Serbian Law on Forests, increasing of the percentage of the special-purpose forests owned by the State is considered as activity of public interest).

The introductory articles of the Croatian Law on Nature Protection, give concise directions related to the purpose and goal of the Law, regulating systemic approach of protection and overall nature preservation. Still, it defines nature in very abstract way as overall biological and landscape diversity. The same also holds for the first article of Serbian Law on Nature Protection which even does not offer the definition of nature as such. As concerns F B-H, the introductory article of the Law on 
Nature Protection clearly defines the scope of the Law as restoration, protection, conservation and sustainable development of landscape, natural areas, plants, animals and their habitats. Comparing to comparable Laws in Croatia and Serbia, this Law is arguably legitimated as a general one within the national legal system. Its provisions shall also be applied for the protection of waters, air, soil, forests and other parts of nature, unless in case these fields are not regulated by special (sectoral) laws.

According to European Commission for Environment, environmental impact assessment (hereinafter EIA) is a procedure which ensures that environmental implications of decisions are taken into account before the decisions are made (EUROPEAN COMMISSION FOR ENVIRONMENT, 2011). The concept of EIA is usually integral part of environmental legislation. As it is written in Article 53 of the Law on Environmental Protection of F B-H: "EIA comprises identification, description, estimation, direct and indirect impact of project and activities on: people, plants, animals, soil, water, air, climate, material goods and cultural heritage (...)." (Official GazeTte F B-H No 33/03) Furthermore, the Law on Environmental Protection of Croatia, (OfFICIAL GaZETTE CROATIA No.110/07) in Article 55, prescribes strategic EIA as the instrument for potential environmental impact assessment caused by implementation of different plans and programs. Similar regulations are prescribed in the Law on Environmental Protection of Serbia (Official GazetTe Republic OF SERBIA No. 135/04, 36/09). To be able to understand how nature protection regulations are integrated into forest related legislation, for the purpose of this paper is further explored in which way the concept of EIA is included in the Laws on Forests. While Serbian Law on Forests prescribes that development plan of forest management area should contain strategic EIA (Article 21), the Law on Forests of F B-H is more precise, especially by regulation of activities such as deforestation and afforestation (Article 16). The Law prescribes that the Federal Minister of Agriculture, Water Management and Forestry, in consent with the Minister responsible for nature protection, prescribes the methodology for EIA of forestry activities. The Law on Forests of Croatia does not mention EIA explicitly.

As concerns environment and biodiversity protection in general, the Laws on Forests include regulations dealing with protected species and their treatment during the day-to-day forest management activities. The Laws in Serbia and Croatia prescribe these issues in general manner. According to the Law on Forests of Serbia, tree cuttings, destroying of the young trees and collection of seeds of species strictly protected by the nature protection regulations is forbidden (Article 13). The Law on Forests of Croatia also prescribes that forest management activities must be conducted in a manner to preserve and improve the biological and landscape diversity: "(...) avoiding the felling of protected, rare or endangered tree species, forest fruit trees and other species of forest berries and protecting and introducing them during the forest rehabilitation (...) (Article 8). Furthermore, Article 47 of the same Law prescribes that forest roads shall be constructed in a way as not to: "(...) endanger the determined ecologically important parts of the forest ecosystems (parts of the ecological network, habitats of rare and endangered species) (...)”. Unlike the 
previous two Laws, the Law on Forests of F B-H has strictly defined the list of species which are excluded from regular forest management activities: "Pasturage in the forest or the use of secondary forest products shall not be allowed if there is a risk of impairing biodiversity or if species of flora and fauna protected by the nature conservation Law would be threatened. It shall be forbidden to cut, to uproot or in any way damage trees of Picea omorika (Pančić) Purk., Taxus baccata L., Acer heldreichii Orph., Pinus mugo (Tura), Alnus viridis (Chaix) Lam. \& DC., Pinus heldreichii (Christ.) and Petteria ramentacea (Sieber) Pres, on their natural sites unless sanitary or tending felling is needed." (OfFICIAL GAZETTE F B-H No. 23/02, ARTICLE 10). The level of detailing in this article can be explained by the fact that the Law on Forests was proclaimed in 2002, before the Law on Nature Protection in F B$\mathrm{H}$. These regulations can be understood as an adaptation on given situation, with the final aim to keep the biodiversity of forest ecosystems unharmed. An additional explanation of these regulations is in the absence of Red list (although it is prescribed by the Law on Nature Protection), neither on entity nor state level, at the time of preparing and adopting the Law on Forests. Red lists are defined in both, Serbia (Official Gazette Republic of Serbia No.36/2009, Article 4) and Croatia (Official GazetTe CROATIA No. 70/05, ARTICLE 7). Whatever, giving the exact list of protected species included in the Law on Forests of $\mathrm{F}$ B-H makes this regulation quite rigid in terms of its adjusting capacities to the changes in biodiversity protection policy.

As protection of soil and water resources is important component of protection regulations within forest related legislation, the articles dealing with these issues are also explored. The Article 3 of Law on Forests of F B-H defines that forests are also in function of soil and water protection. Croatian Law on Forests in Article 3, among all multiple-use forest functions, includes protection of soil from erosion caused by wind and water, water regulations with aim of preventing torrents and high water levels, water purification through soil infiltration as well as ensuring adequate amount of water for subsurface water flows and springs of drinkable water. Similarly, the Law on Forests of Serbia defines water regulations, torrents and overflow preventions, water purification, ensuring water for subsurface water flows and sources of drinkable water and soil and protection of settlements and infrastructure from torrents and erosions as some of the multiple-use forest functions (Article 6). As concerns the regular forest management activities in the context of soil and water protection, the Law on Forests of $\mathrm{F}$ B-H, prescribes that forest transport infrastructure must be built, maintained and used in a way which will not endanger water springs, caused erosion processes, prevent water overflows from torrents, undermined balance in unstable soils and increase the probability for landfalls (Article 13). The Law on Forests of Croatia prescribes similar approach in forest roads' constructions. In Article 47 of this Law, it is written that forest roads must be built, maintained and used in a way which will not endanger water sources, caused erosions, withhold flux of surface and subsurface water flows, increase danger from soil-slides, impede drain of rainfall and flood water which will endanger settlements, viability of forest ecosystems etc. In same article of the Law on Forests, State forestry enterprise or private owner are 
obliged to obtain approval of the public administration competent for environment and nature protection before conducting any activity in planning, construction or opening of new forest roads. Serbian Law on Forests gives the most detailed regulations about soil and water protection. In the Article 7 which deals with obligations and limits of forest owners, it is stated that forest owners are obliged to protect forests and forest land from degradation and erosion. Furthermore, Article 64 (similar as in two above mentioned Laws) prescribes that forest infrastructure (forest roads, fire escape trails as well as other objects) must be planned, built, maintained and used in a way which will not endanger water flows and stability of soils in order to prevent erosions and torrents etc. Specific regulation of this Law, which was not founded in other two, is the Article 50 which prescribes prohibition of changes in forest water regimes. By this Article, drainage and realization of other activities which will change water regime in a way to endanger survival and vitality of forest is prohibited. Also, this Article stated that the arranging of water springs in forests have to be realized in a way which will assure enough water for needs of plant and animal species that live in forests. Surprisingly, only the Law on Forests of F B-H prescribes that Cantonal forestry development plans must respect provisions of water management, inter alia (Article 18). Furthermore, the Law prescribes that forest management plans, land use plans, water management plans, hunting management plans and databases produced by the Institute for Protection of cultural, historical and natural heritage, as well as the federal program of management of certain mineral and minerals must be harmonized (Article 20).

All analyzed Laws on Forests contain regulations by which special categories of forests are established in order to protect soil and water resources. According to the Law on Forests of F B-H (Article 39), these protective forests are proclaimed for two reasons:

a) protection of soils on steep slopes as well as soils endangered by erosion, torrents, landslides and harsh climatic conditions;

b) protection of settlements, industrial and other infrastructure (e.g. roads, energy infrastructure, telecommunication infrastructure, water springs and water streams, banks of water accumulation as well as forests established as belts against natural disasters and catastrophic effects of human interventions.

In Serbian Law on Forests, protective forests include forests for land protection from erosion, protection of springs of drinkable water, well and thermomineral and mineral springs and spas, forests protecting upper vegetation border, water accumulations, railways, roads and settlements (Article 8). In the Law on Forests of Croatia, protective forests are mainly proclaimed for protection of the land, water, settlements, buildings and other property (Article 14).

All three analyzed Laws on Forests intend to ensure respecting of protection regulations regarding to cultural and spiritual values of forests. The Law on Forests of F B-H prescribes that building and maintenance of forest roads and other transport infrastructure must be planned in a way not to harm natural and cultural heritage (Article 13). Furthermore, Cantonal forest development plans need to be prepared in 
accordance with guidelines for management of natural and cultural heritage (Article 18). The Laws on Forests of Croatia (Article 47) and Serbia (Article 64) prescribes building, maintenance and usage of forest roads in a way not to harm natural and cultural heritage. Nevertheless, designating of forests with special management regime, so-called special purpose forest, is the most effective way for ensuring protection of nature and landscape as well as cultural and spiritual values of forests. While protective forests are mainly associated with soil and water protection, functions of special purpose forests are closely connected with nature, landscape and biodiversity protection as well as cultural, historical, educational, spiritual and recreational values of forests (Table 1).

Table 1: Categories of forests with special management regime prescribed by the Laws on Forest in Croatia, F B-H and Serbia

Tabela 1: Kategorije šuma sa posebnim režimom gospodarenja propisane Zakonima o šumama Hrvatske, F B-H i Srbije

\begin{tabular}{|c|c|c|c|}
\hline \multirow{2}{*}{ Categories } & \multicolumn{3}{|c|}{ Countries } \\
\cline { 2 - 4 } & Croatia & F B-H & Serbia \\
\hline Protective forests & $\mathrm{x}$ & $\mathrm{x}$ & \\
\hline Special purpose forests & $\mathrm{x}$ & $\mathrm{x}$ & $\mathrm{x}$ \\
\hline
\end{tabular}

According the Law on Forests of $\mathrm{F}$ B-H, the following forests can be declared as special purpose forests (Official Gazette F B-H, No. 23/02, ARTICLE 40):

a) Forests, or pails thereof, having special cultural, historical, ecological and natural significance, national parks, natural and hunting reserves;

b) Forests of special importance for defense and the needs of the armed forces of the Federation;

c) Forests and forestland of importance for protection of biodiversity and natural habitats of flora and fauna;

d) Forests, or parts thereof, registered as seed stands and facilities to produce seeds;

e) Forests of special importance for science and education;

f) Forests of special importance for purification of air, water supply and quality;

g) Forests designated for the purposes of public rest, general education, recreation, tourism, climatic and other resorts.

In Croatian Law on Forests, special purpose forests are seed stands and facilities for seeds production, forests of special importance for science and education, and forest inside protected areas that are protected by Law on Nature Protection (Article 14). As concerns the Law on Forests of Serbia, the category of special 
purpose forests includes protective forests, but also: “(...) forests for the conservation and utilization of forest tree species gene pool; forests for the conservation of gene, species, ecosystem and landscape biodiversity; forests of significant aesthetic value; forests significant to human health and recreation; forests significant for education; forests for science and research activities; forests of cultural and historic significance; forests for national defense purposes; forests for specific needs of the state bodies and forests for other specific purposes" (OFFICIAL GAZETTE REPUBLIC OF SERBIA No.30/2010, ARTICLE 6). In all three Laws, designating of forests with special aesthetic values as well as those of importance for human health, recreation, education, science, research, culture and history, represent legislative way to ensure protection of cultural and spiritual values of forests.

In all three countries, nature protection legislation prescribes clear categorization of protected areas (Table 2), specifically dedicated in order to protect and maintain biological diversity and natural and associated cultural resources. According to the Article 25 of the Law on Nature Protection of F B-H it is prescribed that :"(...) protected areas shall be established in a form of:

a) protected areas managed mainly for reasons of science or wilderness protection or for conservation through management intervention,

b) national parks managed mainly for ecosystem protection and recreation,

c) natural monuments managed mainly for conservation of specific natural features,

d) landscape protection areas managed mainly for landscape/seascape conservation and recreation."

Croatian Law on Nature Protection contains nine categories of protected areas: strict reserve, national parks, special reserve, nature parks, regional parks, monument of nature, significant landscape, park-forest and monument of park's architecture (Article 8). The Law prescribes that the approval of public forest administration is needed for proclamation of regional park, park-forest and landscape with extraordinary characteristics (Article 21). Besides, it also prescribes development of the program for protection of forest ecosystems as an integral part of management plans for protected areas (Article 42). Serbian Law on Nature Protection contains seven categories of protected areas: strict natural reserve, special natural reserve, national parks, monument of nature, protected habitat, landscape of extraordinary characteristics, nature parks (Article 27). 
Table 2: Categories of protected areas prescribed by the Laws on Nature Protection in Croatia, F B-H and Serbia

Tabela 2: Kategorije zaštićenih područja propisane Zakonima o zaštiti prirode Hrvatske, F BH i Srbije

\begin{tabular}{|l|c|c|c|}
\hline \multirow{2}{*}{ Categories } & \multicolumn{3}{c|}{ Countries } \\
\cline { 2 - 4 } & Croatia & F B-H & Serbia \\
\hline Protected natural areas & & $\mathrm{x}$ & \\
\hline Strict (nature) reserve & $\mathrm{x}$ & & $\mathrm{x}$ \\
\hline Special (nature) reserve & $\mathrm{x}$ & & $\mathrm{x}$ \\
\hline National park & $\mathrm{x}$ & $\mathrm{x}$ & $\mathrm{x}$ \\
\hline Natural park & $\mathrm{x}$ & & $\mathrm{x}$ \\
\hline Regional park & $\mathrm{x}$ & & \\
\hline Nature monument & $\mathrm{x}$ & $\mathrm{x}$ & $\mathrm{x}$ \\
\hline Protected landscape & $\mathrm{x}$ & $\mathrm{x}$ & \\
\hline Park-forest & $\mathrm{x}$ & & \\
\hline Monument of park's architecture & $\mathrm{x}$ & & \\
\hline Protected habitat & & & $\mathrm{x}$ \\
\hline Landscape with extraordinary characteristics & & & $\mathrm{x}$ \\
\hline
\end{tabular}

As concerns the forests with special management regime (protective and special purpose forests designed by the Laws on Forests) and protected areas (proposed by the Laws on Nature Protection), certain discrepancies between authorities at different level are identified in terms of their competencies in declaration. For instance, the Law on Forests in F B-H prescribes that forests with recreation and tourism purposes can be declared by the cantonal institutions, while the Law on Nature Protection prescribes the declaration of these forests (e.g. National Parks) solely by the federal institutions. On the other hand, according to the Law on Forests, the forests of scientific and educational importance are declared by the federal institutions, while the Law on Nature Protection prescribes these forests (e.g. Nature monument) to be declared by the cantonal institutions. The above-mentioned discrepancies are caused due to the use of different terminology for the forests of the same functions.

\section{CONCLUSIONS - Zaključci}

The actual political environment and mobilization of ecologically-oriented interest groups, have given rise to the need for "internationally accepted" concept related to forest resources management. These impacts brought new norms of forest management in Western Balkan countries, mostly resulted in significant reduction of the role of national forest authorities and increasing the influences of nature protection 
authorities. Consequently, new forest legislation, which integrates a number of nature protection regulations, has been adopted to meet changing social, political and economical realities in Western Balkan countries.

While the Laws on Forests deal mainly with forest management activities in details, the Laws on Nature Protection (as a general ones), have broader scope by regulating all nature protection issues. In this context, some authors emphasize a clear distinction between the different scopes and concepts of the Laws on Forests and the Laws on Nature Protection (AvDiBEgOvić ET AL, 2006 ibid). The analysis of introductory articles of the Laws on Forests in Croatia, F B-H and Serbia indicate that forests are managed as multifunctional resource, with the clear objective to preserve biodiversity and strengthen ecological functions of forests. Thus, so-called "green" regulations are well incorporated into the Laws on Forests of analyzed countries. Each of the Laws is treating forests as resources of particular national interests for the society, which makes sound basis for involvement of wide range of actors in forest policy dialogue and eventually steer forest legislation to be more "open" and cooperative.

As regards protection regulations, particularly those related to protection of forest ecosystems and conservation of biodiversity, all three Laws on Forests are rather harmonized with respective Laws on Nature Protection. Furthermore, the Laws on Forests are quite "open" towards the Laws on Nature Protection as many activities prescribed by the Laws on Forests require close cooperation with nature protection sector (e.g. cooperation in prescribing EIA methodology, harmonization of forest management plans with other sectoral plans, regulations related to protection of soil, water, landscape and spiritual values etc.). The imperative to be more open toward other sectors is also represented by the provisions of the Laws on Forests by which forest administration normally would not manage those forests designated to be a part of protected areas that are legally proclaimed by nature protection administration.

Even superficial analysis of forests related legislation leads to the conclusion that forest management regulations in all analyzed Laws, are based on close-to-nature principles by respecting the postulates of nature protection. Still, the European Center for Nature Conservation reports that biodiversity in Western Balkan region is under the serious threat, especially in farmland, mountain regions and coastal zones (ECNC, 2011). Therefore, serious efforts regarding better implementation of protection regulations prescribed by forest related legislation as well as improving day-to-day forest management activities must be conducted. Forest legislation prescribe proclaiming of forests with special management regime (protective and special purpose forest), in order to ensure protection of soil and water regimes, landscape, biodiversity, cultural, spiritual, recreational and other values. Driven by forest certification, some parts of forest have been identified as High Conservation Value Forests (HCVF). The key difference between forests with special management regime and HCVF is that the first ones are prescribed by the regulatory instrument of forest policy (national forest-related legislation) while the second ones are the result of international, private, market-driven initiative (forest certification). The common for both concepts is the intention of forestry sector to be proactive and proclaim some 
forests as forests of outstanding and critical importance due to their high environmental, socio-economic, biodiversity or landscape values. By doing so, forestry sector is shifting from defensive to more active approach related to protection concept and trying to secure stable position in cross-sectoral dialogue around forest resources. By analyzing the elements of HCVF (JENNINGS ET AL, 2003) one can conclude that this concept includes all four components of protection regulations (environment and biodiversity, soil and water resources, nature and landscape, cultural and spiritual values) in quite systematic way. Comparing to legally prescribed designation of forests with special management regime, HCVF represents a voluntarily approach and thus it has strategic magnitude for both, forestry sector and nature protection as such.

The demands on forestry related legislation (and forestry sector in general) to be more "green" might have two possible scenarios:

a) Mandatory, which implies external pressure where forestry sector simply must react subsequently. In this scenario, forestry professionals have very restricted response area and it usually leads to reducing their power over forestry resources. Having in mind modest technical and professional capacities of non-forest authorities in Western Balkan countries to manage forests in a way to focus on their protection as an ultimate management goal, such a concept results in situation that some National parks generate the biggest part of their income from cuttings. It also leads to "artificial openness" and "bureaucratically greening" of forestry sector which results in serious problems in legislation enforcement and poor nature protection.

b) Voluntarily by including awareness, readiness and capacities for change in terms of internal reaction of forestry sector. Implementation of HCVF concept implies active role of forestry professionals and securing at least equal position in dialogue with other sectors. Naturally, this includes thorough openness of forestry sector and human resources capable to understand changing demands of society towards forests. In this context, HCVF cannot be designed through top-down approach based on dominancy of technical authority of forestry professionals. Instead, it must respect forest governance principles, participation, fairness and cross-sectoral cooperation before all.

Historically, management of forest resources was heavily shaped by achieving a balance between individual human needs towards forests and collective socioeconomic realities. The main task of forestry professionals is to implement this balance in practice. By doing so, forestry professionals have always been led by the idea that sustainable managed multifunctional forests provide the highest economic effects and ensure the optimal combination of all other goods and services. The evolution of the society demands towards forest, from the pure economical toward the socio-ecological ones, results that forest related legislation in Western Balkan countries needs to become more open and "greener". On the other hand, specific economical and social realities, makes implementation of nature protection regulations 
proclaimed in forest related legislation at least dubious. In order to develop a comprehensive (effective and efficient) legal framework for nature protection, it is necessary to promote cross-sectoral dialogue and to apply the concept of participatory approach in planning and implementation of forest and nature protection legislation.

\section{REFERENCES - Literatura}

Avdibegović, M. (2002): Forest and Environmental Legislation in the Federation of Bosnia and Herzegovina. Forstwissenschaftliche Beiträge der Professur Forstpolitik und Forstökonomie der ETH Zürich, Vol. 26: 49-60.

Avdibegović, M., KRILAŠević, E., Selmanagić, A. (2006): Collision between Regulations in Forest Laws and Environment Related Legislation in the Federation of Bosnia and Herzegovina. Legal Aspects of European Forest Sustainable Development. Proceedings of the $8^{\text {th }}$ International Symposium in Istanbul / Turkey, Department of Forest Law, Faculty of Forestry, Istanbul University, p. 103

Jennings, S., Nussbaum, R., Judd, N., Evans, T. (2003): The High Conservation Value Forest Toolkit - Part 2 Defining High Conservation Values at a national level: a practical guide, Edition 1, ProForest

Official Gazette Croatia No. 110/07, Law on Environmental Protection

Official Gazette F B-H No. 33/03, Law on Environmental Protection

Official Gazette Republic of Serbia No.135/04, 36/09, Law on Environmental Protection

Official Gazette Croatia No.140/05, Law on Forests

Official Gazette F B-H 23/02, Law on Forests

Official Gazette Republic of Serbia No.30/2010, Law on Forests

Official Gazette Croatia No.70/05, Law on Nature Protection

Official Gazette F B-H No. 33/03, Law on Nature Protection

Official Gazette Republic of Serbia No.36/2009 and 88/2010, Law on Nature Protection

MARTINIĆ, I. (2000): Croatian Forest Law and Environmental Legislation. IUFRO World Series Vol. 10: 76-88.

MARTINIĆ, I., PosaveC, S., ŠPorčlć, M. (2009): Time of intensive changes in environmental and forest legislation for Croatian forestry. Legal Aspects of European Forest Sustainable Development. Proceedings of the $10^{\text {th }}$ International Symposium in Sarajevo, Bosnia and Herzegovina 2008: Faculty of Forestry, University of Sarajevo. 
PROKIĆ, S. (2003): Towards Harmonisation of Legislation Addressing Environment Protection, Forestry and other Natural Resources in the Republic of Serbia. Proceedings of the $4^{\text {th }}$ International Symposium Organised by the IUFRO Research Group 6.13.00, Jaunmokas, Latvia, August 2002. Forstwissenschaftliche Beiträge der Professur Forstpolitik und Forstökonomie, ETH, Zurich, Vol.29: 8391.

SCHMithüSEN, F. (2004): Role of Landowners in New Forest Legislation. Legal Aspects of European Forest Sustainable Development. Proceedings of the 5th International Symposium, Zidlochovice, 2003: 46-56. Forestry and Game Management Research Institute, Jiloviste-Strnady, Czech Republic.

STANIŠIĆ, M., NoNIĆ, D., JoVIĆ, D. (2005): Participatory approach in creation of forestry and environmental legislation in Serbia. Legal Aspects of European Forest Sustainable Development, Proceedings of the 6th International Symposium, Poiana Brasov, 2005: 32-41. Transilvania University of Brasov, Romania.

Tomić, N. M. (2006): New trends in forest and environmental legislation in Serbia. Legal Aspects of European Forest Sustainable Development. Proceedings of the 7th International Symposium, Zlatibor Mountain / Serbia, 2005. Forstwissenschaftliche Beiträge der Professur Forstpolitik und Forstökonomie, ETH, Zurich Vol. 35: 267-274.

\section{Internet Sources - Internet izvori:}

European Commission for Environment, 2011:

http://ec.europa.eu/environment/eia/home.htm (Accessed $6^{\text {th }}$ of December 2011)

European Centre for Environmental Protection (ECNC), 2011:

http://www.ecnc.org/seebap/relevance (Accessed $6^{\text {th }}$ of December 2011) 


\section{SAŽETAK}

Tokom posljednih nekoliko godina, sve zemlje Zapadnog Balkana su usvojile nove Zakone o šumama, uvodeći međunarodno priznate koncepte gospodarenja šumama. Uslijed specifičnih socioloških, političkih i ekonomskih promjena sa kojima se suočavaju ove zemlje, brojne odredbe koje se tiču zaštite prirode su uključene i u šumarsku legislativu. Ovaj rad se bavi uporednim istraživanjem odredaba o zaštiti u Zakonima o šumama Hrvatske (2005), Federacije Bosne i Hercegovine (2002) i Srbije (2010), utvrđujući sličnosti i razlike između navedenih zakona. Osim toga, rad analizira stepen nekonzistentnosti između Zakona o šumama i Zakona o zaštiti prirode Hrvatske (2005), Federacije Bosne i Hercegovine (2003) i Srbije (2009) u smislu otvorenosti i "pozelenjavanja" šumarske legislative.

Rezultati pokazuju da odredbe o zaštiti prirode u šumarskoj legislativi, posebno one koje se odnose na šume sa posebnim režimom gospodarenja, mogu biti osnažene primjenom koncepta šuma visoke zaštitne vrijednosti (HCVF). Ovaj koncept podrazumijeva takođe i strateške promjene u poziciji šumarskog sektora - od inferiornog prema aktivnijoj ulozi u raspravama o zaštiti prirode. Rezultati ovog rada mogu doprinijeti daljem unaprijeđenju postojeće nacionalne šumarske legislative $u$ analiziranim segmentima kao i kreiranju konzistentne šumarske politike i politike zaštite prirode usmjerenih ka jačanju međusektorskog dijaloga i saradnje 